\title{
Destination Brand Management for the Support of Political Identity: The Case of Slovenia
}

\author{
Saša Poljanec-Borić \\ Institute of Social Sciences Ivo Pilar, Zagreb, Croatia \\ e-mail:sasa.boric@pilar.hr
}

\begin{abstract}
This article examines the development of Slovenian competitive identity over the past twenty years through marketing and political perspective. An inception and evolution of a destination brand is considered. The coincidence between the release of Slovenian new brand identities and decisive political steps Slovenia undertook between 1990 and 2007 is analysed in order to show a mutual interdependence between destination branding and political marketing. Since Slovenia started to develop a competitive identity of the country while still in the Socialist Federal Republic of Yugoslavia, it is argued that this was done in order to promote its independence from Yugoslavia. Furthermore, changing of the brand identity occurred whenever a process of the accession to the European Union would reach a decisive point. Therefore, the development of the Slovenian competitive identity after independence was closely coordinated with political aspirations of the country to integrate into the European Union. The conclusive stage of competitive identity development coincides with inclusion of Slovenia into the Schengen and Euro zones. Such a coincidence strongly corroborates a hypothesis that there has been close interdependence of touristic and political marketing during past two decades. Finally, it is suggested that the Slovenian case of destination brand management is unique in new Europe and that it should be evaluated with regard to other relevant destination branding practices in the new Europe and the world.
\end{abstract}

Key words: Tourism, Politics, Marketing, Brand, Competitive identity, Slovenia, European Union.

\section{Introduction}

In modernity, technology is a driving force that has deeply affected communication, transport and travel while homogenizing the world's needs and desires (Levitt, 1983). Also, in modernity, nations compete in order to achieve competitive advantage (Porter, 1998). Therefore, today it is commonly accepted that any nation can be viewed as a brand and as a social and historical compound with relevance for marketing (O'Shaughnessy and O'Shaughnessy, 2000:56). However, the theory of 
nation branding is still in its infancy (Szondi, 2008:4). The term was coined in 1996 by Simon Anholt (Szondi, 2008:4), who published his first scholarly article on nation branding in 1998 (Anholt, 1998; Szondi, 2008:4). Dinnie (2008) argues that the concept of nation branding was derived from sociological, political, cultural and historical approaches to national identity, while Szondi (2008) suggests this concept emerged from destination and place branding studies, which focused primarily on tourism. This is why it is difficult to trace the origin of the concept and why concepts of destination, place and nation branding are often considered to be either strongly related or even synonymous. Thus, Szondi (2008) emphasizes that nation branding can be conceptualized as a special area of place branding and should be considered as a distinct marketing discipline.

Nations try to protect certain images or a set of values to help exports or tourism. On the other hand, nations use solidarity appeals to their nationals in order to build awareness of national identity as this helps govern the country (O'Shaughnessy and O'Shaughnessy, 2000:61). Holt, Quelch and Taylor (2004) suggest that "glocal“ i.e. hybrid marketing strategies are ruling the contemporary marketing scene due to globalization. Those marketing strategies aim at impressing consumers globally by embedding brands as deeply as possible into local socio-cultural settings to assure good reception for the brands on local markets (Holt et al., 2004). Within such a marketing context it is not surprising that nations use branding and marketing communication techniques to promote a nation's image (Fan, 2006:6). Anholt (2007) argues that countries should engage not only in promoting a nation's image, but also in effective brand management and a competitive identity building in order to compete with each other for share of the world's consumers and tourism. Effective brand management deals with four dimensions of brand: identity, purpose, image and equity. Brand identity is a core concept clearly expressed by logo and slogan. Brand purpose is an idea similar to „spirit of the organization“ and „common purpose“. Brand image is virtually the same thing as reputation. Finally, brand equity is an intangible capital acquired by solid reputation that represents the ability of brand to trade at healthy margins as long as the image stays intact (Anholt, 2007:56). On the other hand competitive identity is a more complex concept as it is the synthesis of brand management with public diplomacy, trade, investment, tourism and export (Anholt, 2007). This holistic concept developed by Anholt (2007) has been vital for understanding the process of Slovenian destination brand management within the context of destination and nation branding practices that occurred in the new Europe ${ }^{1}$ since 1990 (Hall, Smith and Marciszewska, 2006). Therefore, a short explanation of a nation branding activities in new Europe is of interest for further discussion.

$\mathbf{1}$ The term new Europe is used in this article to indicate Central and Eastern European countries that have moved into the camp of democracies in the late eighties of 20th century. Cf. Lehning, B. P and Weale, A. (1997) Citizenship, democracy and justice in the new Europe, London:Routlege. 


\section{Nation branding in the new Europe and specificity of Slovenian case}

A number of countries of new Europe such as Hungary and Poland (Hall et al., 2006) used tourism campaigns for destination and nation branding purposes, because they wanted to reposition themselves as macro destinations and nations after the fall of the Berlin Wall (Hall, 2004). Countries of the new Europe wanted to attract greater numbers of visitors to their respective countries in order to profit from the market liberalization, an immediate socio-economic effect of the political end of Cold War. However, contrary to Spain, Greece and Austria - countries that also launched highly visible nation branding campaigns (Poljanec-Borić, 1994; Gilmore, 2002) inspired by aims such as changing of the type or increasing the tourism demand (Avraham and Ketter, 2015) - new European countries were „newcomers" to the market arena. They were all trying to create a new image (Fan, 2006) for their countries because they wanted to overcome their negative socialist and Eastern European image (Szondi, 2007). However, the mentioned countries were primarily entangled with their transitional agenda (Offe, 1991). Therefore, it is very likely that these transitional circumstances made their marketing strategies and subsequent rebranding choices a rather ephemeral issue in the complex system of transitional changes.

Within the mentioned transitional context of new European countries, Slovenia stands as one of the countries that had put brand management efforts ahead of all the other transitional policies and had started complex brand management activities prior to becoming an independent state. Slovenia, created its first brand identity promoting Slovenia as a unique tourism destination already in 1986 (Konečnik Ruzzier, 2012) while it was still a part of another country, the Socialist Federal Republic of Yugoslavia (SFRY) and while nation branding theory was rather nonexistent (Szondi, 2008). Therefore, it is of interest to investigate the Slovenian brand management case in order to provide important insight into a specific branding practice in the new Europe that started prior to the fall of Berlin Wall. This will not only inform the existing body of knowledge on the subject matter of place branding (Szondi, 2008) but will also help understand social context in which nation branding activities were undertaken in transitional (Offe, 1991) and global conditions (Levitt, 1983; Holt et al., 2004; Anholt, 2007, 2008).

\section{Aim and purpose of the study}

Even though links of tourism and democracy are not self-understanding (Richter, 2007), the specific timing of Slovenian active engagement with nation branding through tourism allows us to hypothesize that destination branding in Slovenia had distinctive political roots embedded in a pro-democratic social dynamics (Tulmets, 2014). As this very fact is a rather unusual political circumstance, an informed insight into this topic should be of wider interest. Therefore, the aim of this study is to analyse the inception and evolution of Slovenian brand identities through political and marketing perspectives. The purpose of the study is to show that as of 1986 there was a consistent coordination between strategic tourism marketing activities aimed 
at developing a competitive destination brand for Slovenia and political efforts of Slovenian political stakeholders to acquire independence for the country and to integrate the country as quickly as possible into the European Union (EU). Thus, it is suggested that Slovenia, de facto, engaged in building competitive identity of the country (Anholt, 2007) prior to any other new European country without being able to consult any specific conceptual framework for such a practice. Drawing on Pal's (1989) insight that a policy is deemed as public policy by virtue of its source, the analysis will be focused on the official campaigns released between 1986 and 2007 first by a relevant Slovenian agency and later by Slovenian Tourist Board ${ }^{2}$ (STB).

\section{The method}

The method used to acquire insight into Slovenian nation branding practice is a case study based on observation and secondary literature analysis. The observation aspect includes following the precise temporal changes of brand identity elements: logo and slogan. Logo and slogan are the quintessence of brand identity (Kottler, Bowen and Makens, 1998) and key to understanding nation branding of particular country (Anholt, 2007, 2008; Pike, 2008). Given the O'Shaughnessy and O'Shaughnessy (2000) insight that nations try to protect certain images or set of values to help exports or tourism while using solidarity appeals to their nationals, the observation of Slovenian brand identity evolution was coupled with desk analysis focused on political events relevant for Slovenian recent history (Tulmets, 2014). Key visual and verbal messages released by STB over the period of twenty years were compared in the context relevant for recent Slovenian political history. The comparative analysis looked at a logo and slogan level of campaigns at different stages of nation building (Brubaker, 1996) and the process of the accession to the European Union. Therefore, a number of secondary sources such as books, articles, policy documents and news reports were consulted in order to understand the socio-political factors (Offe, 1991; Lindstrom, 2003; Tulmets, 2014) that impacted on the nation branding process in Slovenia and to establish the links between those socio-political factors and nation branding practices.

\section{The discussion}

\subsection{A political root of destination branding practice in Slovenia}

Slovenia entered the EU in 2004. The entry occurred within a political „big bang“ process of EU enlargement with eight new member states from new Europe and with the island/state of Malta joining the Union. Beside the fact that the voluntary

2 Slovenian Tourist Board is an equivalent of National Tourist Office. It is a major national tourist organization for planning and performing the promotion of the country as a tourist destination. 
integration into EU structures and the extension of EU jurisdiction to nine new members at once was a spectacular political success, it sent, at the same time, an underlying message to small European nations with a socialist past. Namely, six out of the nine countries which integrated in 2004 had achieved independence only after the fall of the Berlin Wall. Therefore, the underpinning political message was that, in post-communist Europe, national independence was welcomed by the EU as long as a particular, newly established country could, simultaneously with nation building (Brubaker, 1996), demonstrate the capacity to manage a triple transition (Offe, 1991), i.e. adopt capitalism, build state institutions, and to incorporate the acquis communautaire into its historically specific socio-cultural and socio-economic fabric (Schimmelfenning and Sedemeir, 2004).

Within the mentioned club of newly independent nation-states, which integrated in 2004, Slovenia was the only ex-Yugoslav country able to achieve both independence and integration in the period of only thirteen years ${ }^{3}$. Undoubtedly, gaining independence from Yugoslavia required a highly structured agenda and strong political sense of direction, an insight strongly corroborated by the fact that two other ex - Yugoslav republics, Croatia and $\mathrm{BiH}$, in particular, had experienced long-lasting violent conflict and war in order to achieve it. On the other hand, EU accession was an institutionally demanding and lengthy process. To master the process in a timely manner, a politically coherent and structured institutional drive toward independence and ultimately EU accession had to be in place already while Slovenia was still a part of the SFRY. This insight is precisely the point at which the activities of a STB become relevant for an analysis of the links between political dynamics and nation branding practices.

„Centre for tourism and economic advertising“ (Center za turistično in ekonomsko propagando) was established on October 1, 1983 in the Slovenian capital Ljubljana (STB, 2011). The mentioned Centre had a strong political support of the President of then Slovenian government, Mr. Dušan Šinigoj, ${ }^{4}$ (STB, 2011). Evidently, the support was rather generous because a highly visible campaign „Slovenia moja dežela“ (Slovenia, my country) was launched later in 1986, four years before the collapse of SFRY. Besides a very persuasive slogan emphasizing the strong connection with the identity of a territory, the campaign publicly disseminated a logo featuring Slovenian name with the lime leaf placed symbolically in the middle of the name. According to the relevant information 5 , the campaign was (at the beginning) strictly created with a purpose to brand Slovenia as a tourist macro destination. However, subsequent changes of political circumstances in SFRY at the end of eighties in $20^{\text {th }}$ century gradually transformed the newly promoted brand into a political identity symbol.

3 Slovenia declared independence on June, 25, 1991.

${ }^{4}$ Mr. Dušan Šinigoj, born in 1933, was Prime Minister of Slovenia from 1984 to 1989. He was a member of the League of Communists of Slovenia until 1989 when he became a member of the Party of Democratic Renewal.

5 Information was given by the authors of the campaign. 
Picture 1

The first Slovenian NTO logo released in 1986

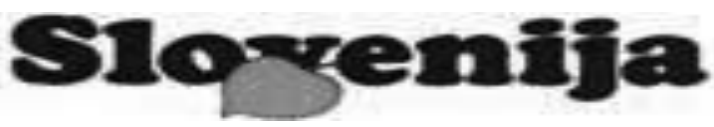

Source: STB (2011)

A contextual understanding of the meaning of a brand identity (Picture 1) released in 1986, reveals the reasons why this particular destination brand transformed in a national identity symbol in only few years' time. Firstly, the logo and slogan omitted the typical designation „socialist republic“. This was, at that time, a highly unusual communication practice in the SFRY. Secondly, by placing a lime leaf right in the middle of the Slovenian national name, the campaign subtly announced a desire to overcome both the socialist character of the still federal state and the Yugoslav geopolitical frame. With the lime tree being a symbol which figures centrally in Slovenian folk tradition, one could hardly doubt the underlying message of such a logo. Lime trees can be found on the main squares of towns all over Slovenia and, following tradition, a lime tree was planted on Boris Kidrič square in Maribor, to celebrate the declaration of independence in 1991. The lime tree with its strong roots and longevity has traditionally been used for land demarcations, for household instruments, and also in religious artworks in Slovenia 6 . The lime tree and its rich shade was a centre of community life in Slavic traditions (Vinšćak, 2002), a place where public voice was articulated and some centuries old trees have even been given names by the local population. Hence, a publicly promoted lime leaf ${ }^{7}$ placed in the middle of national name featured in the campaign that centred primarily on self - confidence of Slovenians was very well welcomed in Slovenia at that time. Such a favourable public reaction to a campaign that „truly found its way into the hearts of Slovenians“ (Konečnik Ruzzier, 2011) probably encouraged Slovenian marketing experts to push the process of destination branding further in pro-independence direction. This underpinning political „sense of direction", which managed the process of Slovenian destination branding, was well explained in an interview given at the occasion of the $20^{\text {th }}$ anniversary of Slovenian independence by the last President of the Presidency of the Socialist Republic of Slovenia Mr. Milan Kučan: „It would be an exaggeration to say that it was already clear to me then how things would develop, but I knew that Yugoslavia, such as it was, did not have a future, which is why I endeavoured from the mid-eighties to gain allies for a new agreement, or failing that, at least agreement to a peaceful departure from Yugoslavia. We wished to place the Yugoslav federation on a new footing: we were not yet considering independence. It was only after our ideas fell on barren soil that it became necessary to contemplate independence" (Kučan, 2011).

\footnotetext{
$\mathbf{6}$ The famous Holy Mary of Ljubno (Gorenjske) and the figures of saints on the high altar of the Daniel Church in Štanjel on the regional street Sežana - Nova Gorica are made of lime wood.

7 Lipa means lime tree in both Slovenian and Croatian. „Lipa“ was introduced in Croatia as a currency denomination, next to „kuna“ when Croatia achieved independence in 1991. Slovenes and Croats, after all, share a same Slavic socio-cultural traditions (Katičić, 2013).
} 


\subsection{The re-positioning phase: from weak image to well-known brand}

In 1987, strongly encouraged by an overwhelming success of „Slovenia, my country“ campaign, and strongly discouraged by „barren soil“ of then Yugoslav political setting, Slovenia released a campaign targeting a foreign audience with the slogan: "Slovenia, the sunny side of the Alps", thus advertising its new brand identity. At the same time Slovenia was already working on its brand purpose (Anholt, 2007) by running the slogan „Tourism is people“ targeting domestic audience in order to encourage residents to implement the Slovenia's new alpine brand identity on domestic market (Konečnik Ruzzier, 2011). These simultaneous marketing activities aimed at repositioning the country on foreign markets and creating a new, participative touristic "organisational culture“ in Slovenia had two purposes: touristic and political. The touristic purpose was to divorce the experience of visiting Slovenia from Yugoslav attributes and to re-create an Alpine image of the country based on genuine natural resources and geographical position by emphasizing its AlpineMediterranean character. In „sunny side of Alps“ slogan, Slovenia was positioned as distinctively Alpine country, while its Mediterranean character was promoted by the „sunny“ condition in order to differentiate Slovenia from other European Alpine countries such as Austria and Italy. The marketing strategy Slovenian experts were using in this stage of brand management was to link Slovenia as a macro destination with a weak image at that time with Alps as a macro destination with a well-known brand (Beirman, 2003). The marketing aim of this campaign was to create a new unique selling proposition (Kotler et al., 1998) for the country in order to reach out to a new demand (Avraham and Ketter, 2015). The new demand that Slovenia was looking for was primarily on Western markets as Slovenian marketing experts were aware of market constraints that would, suite to political liberalization, influence the intra East European travel patterns (Richter, 2007:9). The intention to link Slovenian competitive positioning to Alpine and Mediterranean characteristics seemed logical from a competitive destination branding perspective. It was highly structured because it aimed at developing two dimensions of brand: identity and purpose by repositioning from Yugoslav and Balkan attributes and by encouraging new organisational culture. At the same time it was developing a third dimension of brand an image - (Anholt, 2007) by emphasising the sunny (Mediterranean) character of Slovenian Alps as a key difference with regard to other Alpine countries. Again, as in the case of "Slovenia, my country“ slogan, this „alpine“ repositioning was very well accepted by the travel and tourism industry. The most powerful proof for this statement is the fact that contemporary travel and tourism advertisers still refer to the first international Slovenian campaign in following words: „Such a tiny piece of the world that with a glance on Google Earth at a height of $39.4 \mathrm{~km}$ you will experience everything in a single moment, the Alps and the Mediterranean in one view! TAKE A BREAK! Visit Alpine Slovenia!“ (Slovenian Alps, 2014).

However, from the political point of view, the whole Slovenian marketing activity was highly atypical within the then socialist, federal and Yugoslav context. Nothing similar was either produced or released in other constituent parts of the then still unified country. And nothing similar could have been produced in other parts of 
the country without causing a major political scandal. ${ }^{8}$ This very fact, indeed, suggests that the Slovenian tourism campaigns prior to 1990 were politically driven by domestic political stakeholders (Kučan, 2011) and maybe even politically supported, by international political forces (Etzioni, 2004). The obvious parallel dynamics between development of a highly structured new destination brand which, in fact, had all the characteristics of nation brand and the decisive political steps Slovenia took in 1990 only further corroborate this supposition.

Namely, in 1990 Slovenia released a public awareness campaign „Europe now!“ („Europa zdaj!“). This slogan „Europe now“ was a dominant feature of the opposition movement in 1990 which campaigned for Slovenian independence (Lindstrom, 2003:1 in: Tulmets, 2014:58). The definition of Slovenia as a European state had, according to Lindstrom (2003) a discursive meaning through which political leaders could accomplish several interrelated goals such as securing the international recognition of Slovenia as a sovereign state, differentiating Slovenia's national identity from Yugoslav or Balkan ones and legitimating a new Western political and economic orientation that would facilitate Slovenia's transition to a democratic and free - market state (Lindstrom, 2003:1 in: Tulmets, 2014:58-59). The first Prime Minister of the independent Slovenia Mr. Lojze Peterle clearly summarized what the „Europe now!“ slogan actually meant in the following paragraph: „Independence was a precondition for a free future. We actually had two demanding tasks - to set up an independent state and to break away from communist totalitarianism. Only as an independent and democratic entity were we able to rely on international recognition and the integration of Slovenia in the EU and NATO. Our vision was based on a willingness to truly share values and principles with EU. This meant putting an individual at the centre, establishing the rule of law and social market economy" (Peterle, 2011 cited in Tulmets, 2014:58-59).

Not surprisingly the slogan „Europe now“ was consistent with the 1986 tourism campaign "Slovenia, my country“. No other Yugoslav republic had the capacity to publicly promote such a pro-integration slogan at that time. Among six constituent socialist republics of ex-Yugoslavia, Slovenia was the only one that had modern statehood internally constructed and nation branding process mastered already in 1990.

\subsection{Brand management in the accession period}

The accession process to the European Union is a lengthy one (Schimmelfenning and Sedemeir, 2004). Therefore, the lime leaf campaign ended only in 1996 when it was simultaneously replaced by a bundle of flowers and the slogan „Slovenia the green piece of Europe“ (Konečnik Ruzzier, 2011). Knowing that Slovenia was successful in divorcing Yugoslavia only after it started the separation process four years before the divorce actually became official, it seems only logical that the country's

8 Only a mild Croatian public support for the Alpe - Adria working community (Hyde-Price, 1996) produced an outrage in other parts of then Yugoslavia, labeling Croatians as „Viennise horsekeepers". 
tourism experts and political stake holders used the same approach in building public awareness about the EU accession. This time Slovenia was dealing with a much easier political task than when dealing with separation from Yugoslavia. Namely, ex-Yugoslavia discouraged separation while European Union encouraged integration. Therefore, Slovenia embarked on a new repositioning mission two years prior to institutionally starting the accession process.?

Picture 2

Slovenian logo released in 1996

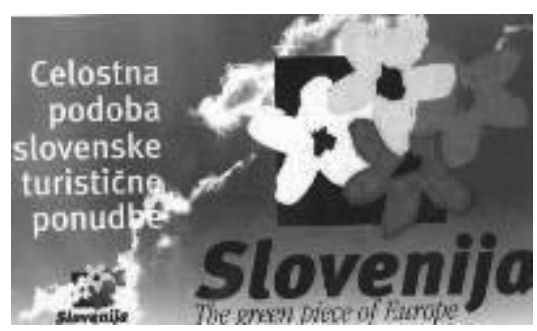

Source: STB (2011)

In order to enrich the central "green piece“ message of the campaign and to maximize subsidiary and local support for the marketing and political aims, STB developed and released a number of local, tailor - made, mini - campaigns in the Slovenian language. All those mini campaigns aimed at asserting the new brand purpose i.e. building internal cohesion in order to support the development of place based tourism (Keller, 1999) a development strategy congruent with the political integration in the European Union (Barca, 2009). Between 1995 and 2002 at least six such campaigns were released which aimed at capacity building of regional tourism supply value chains. Campaigns celebrating a) social cohesion (ex. „Imamo se fajn“ - „Together we are great“, 1996) and b) „nostalgic" (Mollegaard, 2005) atmosphere (ex. „Dobrodošli doma“ - „Welcome home“ 1998; 1999; 2000) indirectly corroborate this presumption.

The campaign „Green piece of Europe“ was operational until 2004 the year of accession of Slovenia to the European Union. It helped Slovenia recover the number of tourists and overnight stays that dramatically fell after 1991. In fact, in 2004 Slovenia realized almost 2 times more arrivals and overnight stays than in 1995, registering roughly 1.5 million arrivals and 4.5 million overnight stays in 2004 . Moreover, the number of international tourists and overnight stays in Slovenia was increasing in such a way that in 2004 compared to 2003 grew by 10\% representing an even higher growth rate than recorded for this period by either the number of foreign tourist (9\%) or their overnight stays (4\%) (Konečnik, 2006 in: Hall et al., 2006:84). In other words, by 2004 Slovenia had established its brand identity and strengthened its' brand purpose. Therefore, the country was ready for both: to achieve its political aim to join the European Union and to compete on a global tourism market with a new nation brand (Anholt, 2007).

9 Slovenia started accession negotiations on 31 March 1998. 


\subsection{Adapting nation branding to EU membership}

The increased number of tourist arrivals and overnights registered in 2003 suggest that the campaign "Slovenia - The green piece of Europe" was instrumental to the national travel and tourism industry. Also, it was instrumental for various dimensions of competitiveness ${ }^{10}$ stemming out of inherited or created resources (Gomezelj Omerzel, 2006). Nevertheless, Slovenia ended „The green piece of Europe“ campaign that started in 1996 exactly in 2004.

Coinciding with European Union membership, in 2004 Slovenia featured a new slogan „Slovenija poživlja/Slovenia invigorates“ while keeping operational a 1996 logo with „bundle of flowers“. This move would be hard to explain from the marketing point of view if a political dimension would not be primarily considered. Namely, it is rational to conclude that such an incomplete strategic move of STB was determined by the fact that political marketing aim came as first while destination's branding came as second when devising this campaign. It is rational to assume that Slovenian political stakeholders were overwhelmed by their success in 2004 and that they moved faster than they should in order to keep pace with the atmosphere they were surrounded in the 2004. Even though the semantically elastic word "poživlja“11 (invigorates) used in that campaign was probably meant to serve political and touristic purposes at the same time, the move was, for the first time in the analysed temporal sequence, „half-cooked“.

It is true that "Slovenia invigorates" could have been interpreted in political terms, as reflecting successful navigation through transitional turmoil (Offe, 1991) to European (post)modern political and social dynamics (Inglehart, 1997) and national competitiveness (Porter, 1998). It is also true that „Slovenia invigorates“ could have been interpreted from the experience economy (Pine and Gilmore, 1999) paradigm perspective as suggesting that Slovenian accession to the EU actually meant adding value to the old continents supply chain by bringing in Slovenia as a new and fresh „experience“.

However, despite the fact that "Slovenia invigorates" campaign constituted the first attempt to establish a competitive identity (Anholt, 2007) and thus create nation brand that was instrumental not only in tourism but also in other areas, the campaign was unsuccessful because foreigners as well as Slovenians did not understand the campaign and slogan and did not accept it very well (Konečnik Ruzzier, 2011). The campaign was discontinued in 2006. An end to a difficult and lengthy nation branding process, called for a time out. It took only a year to Slovenian marketing experts to rethink the process and deliver a solution again in coordination with a finalization of a major political process.

\footnotetext{
$\mathbf{1 0}$ In a survey conducted in 2004 Slovenia was regarded above average on all attributes on dimension of inherited resources and on some important dimensions on created resources such as: health resorts, variety of cuisine, nature based activities, food service facilities, etc. (Gomezelj Omerzel, 2006:174-176).

11 Indeed the Slovenian verb „poživljati“ has an elastic meaning ranging from: „to invigorate“ to „reanimate“ or in Croatian from: „okrijepiti“ to „oživjeti“.
} 


\subsection{Competitive identity defined}

In 2007 coinciding with the admission to the Eurozone and Schengen, Slovenia released a new emotionally appealing campaign entitled „I feel Slovenia“ with the words „I“ „feel“ and „love“ highlighted as shown below:

Picture 3

Slovenian logo released in 2007

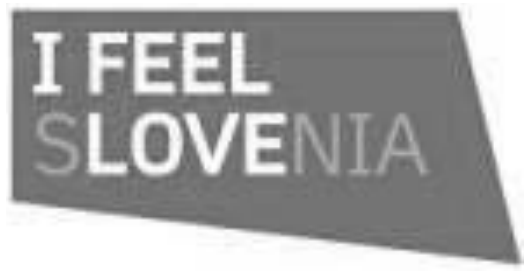

Source: STB (2011)

The word „love“ in 2007 was placed right there where, twenty years before, a „lime leaf" discreetly announced the beginning of the political separation from Yugoslavia. Also, what once was a "piece“ of Europe has become a green partner in Europe, embedded in experience economy (Pine and Gilmore, 1999) as powerfully suggested by the logo. By delivering this new brand identity in 2007 Slovenia strongly suggests the intention to co-create environmental policies within the European Union, to insist on national social cohesion and to compete on global markets as it is selfunderstanding that the word „love“ works globally and locally (Holt et al., 2004). It suggests not only need for social cohesion within Slovenia, but also a possibility for anybody who visits Slovenia to experience „love“. Konečnik Ruzzier (2012:125-126) argues that the 2007 project represented the first serious step toward developing the Slovenia brand since Slovenia's independence as it built the basic foundations of the new Slovenia brand from the perspective of all internal stake holders. Moreover, the same author emphasises, that the approach was of a holistic nature, as relevant areas (i.e. commerce, tourism culture, science, sport) and related key stakeholders that affect and co-create the Slovenia brand identity had been determined in advance.

Although the judgment by which „the 2007 project represents the first serious step toward developing the Slovenia brand since Slovenia's independence" (Konečnik Ruzzier, 2012:125) is not persuasive given the implications of previously analysed evolution of Slovenian brand identity, the judgment is informative and relevant. The fact that the experts judge the creation of this brand as very "serious" and professionally completed job, only shows that this particular phase of brand development activity was done through a very informed, „state of the art" process because Slovenian marketing experts and political stake holders decided to „stabilize“ the nation brand and to define a competitive identity of a nation in global context, once the political process the country was engaged in from 1986 was completed. Therefore, the professional path which was taken in order to develop this particular competitive identity only corroborates the assumption that Slovenian political stakeholders and tourism experts were keeping pace with the time and that they were fully aware 
of the strategic contents and goals of every single decisive international tourist campaign launched in Slovenia within the last twenty-five years.

This last decisive step that occurred when Slovenia entered Schengen and Euro zones is a signal that in 2007 Slovenia concluded its national identity component of branding and put greater emphasis on its competitive content. It is interesting to note within this context that in 2010 Slovenia has broadened its concept of national security by including new national security objectives such as effective functioning of the welfare state and efficient environmental protection as well as preservation of natural environment (Krippendorf, 1977) in its National Security Strategy (Riedel, 2013:24). This should be a sign that disconnection of politics and tourism in Slovenia actually meant reconnection of competitiveness and national security in Slovenia. Namely, by adopting a new national security concept where efficient environmental and natural protection are central issues, Slovenians have proclaimed that the interests that are vital for tourism competitiveness are also Slovenian national security interests in the era of global competition.

\section{Conclusion}

Bearing in mind all that has been shown in the previous analysis, the coincidence of dates demarcating independence and the different stages of the Slovenian accession to the EU with the release of specific tourist campaigns was remarkably coherent both with regard to timing and with regard to content. Therefore, it is hard to believe that this temporal sequence coupled with mix of messages that were disseminated might not have been intentional and rational. It seems rational to conclude that in the case of Slovenia, destination branding was used as a tool to promote independence while this particular political agenda was not yet acceptable within wider Yugoslav political system. Also, Slovenian brand identities have been professionally created because the creative actors of the process were highly informed of the state of the art marketing and branding practices that have become widespread over the period of twenty years (Gertner, 2011).

The original concept that centred on self - confidence of Slovenians at the time of achieving independence has been subtly upgraded and elaborated congruently with EU integration efforts. At the same time all the campaigns have consistently been created in a way to address substantial marketing challenges related to the creation of competitive brand identity of the country in an ever growing competitive realm. The remarkable increase in earnings from foreign tourists in Slovenia in the period from 1995 to 2012 (STB, 2012) may be read as a sign of very sound and successful strategic marketing choices. Thus, the campaigns were constantly supporting both aims: the political and the marketing ones with same strength and quality. The path Slovenia took from subtly using national symbols in tourism marketing in order to support nation building (Brubaker, 1996) and independence after the fall of the Berlin Wall while simultaneously preparing for a global competitive positioning in expectation of the dramatic political resolution of the Yugoslav crisis is highly consistent. The link between „lime leaf", "green piece“ and S,Love“NIA is a strategic one. Also, the brand management process has evolved from place and nation branding market- 
ing concepts to competitive identity concept. The fact that Slovenia today is able to analyse all the keywords digitally communicated by tourists who have experienced Slovenia (STB, 2012) allowing for constant revaluation of its competitive positioning on the local level, suggests that the country is further adapting to European competitive realm by focusing on place based tourism (Davenport and Anderson, 2005) and by using digital technology to monitor development of places (Keller, 1999) or maybe even to develop „place shaping“ policies (Lyons, 2007; Van de Walle, 2010).

Judging from the present, Slovenian case is an extraordinary touristic and political story that should be further investigated within the context of nation branding and competitive identity development practices in new Europe. This case study should therefore be understood as a contribution to the informed understanding of transitional tourism marketing strategies applied recently across new Europe. Hopefully, such an informed insight could help in evaluation of campaigns released in past twenty-five years across new Europe. Also, it could help other countries in the world aspiring to brand their nations and build competitive identity for their countries to define their marketing strategies and manage their branding practices in a coherent and result oriented way.

\section{References}

1. Anholt, S. (1998). Nation Brands of the $21^{\text {st }}$ Century, Journal of Brand Management, 5 (6): 395-406.

2. Anholt, S. (2007). Competitive identity: The New Brand Management for Nations, Cities and Regions. London: Palgrave-MacMillan.

3. Anholt, S. (2008). Place Branding: is it marketing or isn't it?, Place Branding and Public Diplomacy, 4 (1): 1-6.

4. Avraham, E. i Ketter, E. (2015). Vrijedi li isto mjerilo za sve? Diferencijacija ciljeva destinacijskog marketinga i strategije za njihovo postizanje. Turizam, 63 (3): 319-336.

5. Barca, F. (2009). An Agenda for a Reformed Cohesion Policy. A place-based approach to meet European Union challenges and expectations. Accessed on November 25, 2015. Available at: (http://www.europarl.europa.eu/meetdocs/2009 2014/ documents/regi/dv/barca_report_barca_report_en.pdf).

6. Beirman, D. (2003). Restoring Tourism Destinations in Crisis. Cambridge, UK: CABI.

7. Brubaker, R. (1996). Nationalism Reframed: Nationbood and the National Question in the New Europe. New York: Cambridge University Press.

8. Davenport, A. M. and Anderson, H. D. (2005). Getting from Sense of Place to Place - Based Management: An Interpretive Investigation of Place Meanings and Perceptions of Landscape Change. Society \& Natural Resources: An International Journal, 18 (7): 625-641.

9. Dinnie, K. (2008). Nation Branding. Concepts, Issues, Practice. Oxford: Butterworth - Heinemann.

10. Etzioni, A. (2004). A Self-Restrained Approach to Nation Building by Foreign Powers. International Affairs, 80 (1): 1-17.

11. Fan, Y. (2006). Nation branding: What is being branded? Journal of Vacation Marketing, 12 (1): 5-14. 
12. Gertner, D. (2011). Unfolding and Configuring Two Decades of Research and Publications on Destination Marketing and Destination Branding. Destination Branding and Public Diplomacy, 7 (2): 91-106.

13. Gilmore, F. (2002). A Country - Can It Be Repositioned? Spain - the Success Story of Country Branding. The Journal of Brand Management, 9 (4/5): 281-293.

14. Gomezelj Omerzel, D. (2006). Competitiveness of Slovenia as a Tourist Destination. Managing Global Transitions, 4 (2): 167-189.

15. Hall, R. D. (2004). Branding and National Identity: The Case of Central and Eastern Europe, in: Morgan, N. and Pritchard, A. (Eds.). Destination Branding: Creating the Unique Destination Proposition - Second Edition. Oxford UK, Burlington, MA, USA: Elsevier Butterworth - Heineman.

16. Hall, R. D.; Smith, K. M. and Marciszewska, B. (2006). Tourism in the New Europe, The Challenges and Opportunities of EU Enlargement. Oxfordshire, UK \& Cambridge, MA, USA: CABI Publishing.

17. Holt, D.; Quelch, J. and Taylor, L. E. (2004). How Global Brands Compete, Harvard Business Review, September Issue. Accessed on February 10, 2016. Available at: (https://hbr.org/2004/09/how-global-brands-compete).

18. Hyde-Price, A. (1996). The International Politics of East Central Europe. Manchester, UK: Manchester University Press.

19. Inglehart, R. (1997). Modernization and Postmodernization: Cultural, Economic and Political Change in 43 Societies. Princeton, NJ: Princeton University Press.

20. Katičić, R. (2013). Hrvatski jezik (Croatian Language). Zagreb: Školska knjiga.

21. Kelller, P. (1999). Future-Oriented Tourism Policy: Strategic Areas of Inquiry. AIEST (1999), in: AIEST (1999). Future-Oriented Tourism Policy, a Contribution the Strategic Development of Places, (41): 7-23, Reports of 49th Congress.

22. Konečnik Ruzzier, M. (2011). Country Brands and Identity: Slovenia. Accessed on March 15, 2015. Available at: (http://www.slovenia.info/pictures/event/atachments_1/2011/konecnikruzzier_dbb_ifs2011_12010.pdf).

23. Konečnik Ruzzier, M. (2012). Developing Brand Identity for Slovenia with Opinion Leaders. Baltic Journal of Management, 7 (2): 124-142.

24. Kottler, Ph.; Bowen, J. and Makens, J. (1998). Marketing for Hospitality and Tourism, Second Edition. UpperSaddle River, NJ: Prentice - Hall, Inc.

25. Krippendorf, J. (1977). Les dévoreurs de paysages: le tourisme doit-le détruire les sites qui le font vivre? Lausanne: 24 Heures.

26. Kučan, M. (2011). Interview: Milan Kučan and Lojze Peterle „Today, Dreams are Allowed, Tomorrow is s New Day.". Accessed on May 11, 2014. Available at: (http://www.twenty.si/first-20-years/overview/before-and-now/interview).

27. Lehning, B. P. and Weale, A. (1997). Citizenship, democracy and justice in the new Europe. London: Routledge.

28. Levitt, Th. (1983). The Globalization of Markets, Harvard Business Review, May Issue. (Accessed on February 10, 2016). Available at: (https://hbr.org/1983/05/theglobalization-of-markets).

29. Lindstrom, N. (2003). 'Between Europe and the Balkans: Mapping Slovenia and Croatia's 'Return to Europe' in the 1990s'. Dialectical Anthropology, 27 (3-4): 313-329.

30. Lyons, M. (2007). Lyons Inquiry Survey. Crown Copyright. Accessed on May 11, 2013. Available at: (http://www.lyonsinquiry.org.uk/).

31. Mollegaard, K. (2005). Aloha Ahoy: Tourism and Nostalgia at Honolulu Harbor. Journeys of Discovery, eSharp, Issue, 4: 1-14. 
32. Offe, C. (1991). Capitalism by Democratic Design - Democratic Theory Facing the Triple Transition in East Central Europe. Social Research, 58 (4): 865-892.

33. O'Shaughnessy, J. and O'Shaughnessy, J. N. (2000) Treating the Nation as a Brand: Some Neglected Issues, Journal of Macromarketing, 20 (1): 56-64.

34. Pal, L. A. (1989). Public Policy Analysis: An Introduction. Calgary: Nelson Canada.

35. Pike, S. (2008). Destination Brand Positions of Competitive Set of Near-Home Destinations. Tourism Management, 30 (6): 857-866.

36. Pine, J. D. and Gilmore, J. M. (1999). The Experience Economy: Work is Theatre $\&$ Every Business a Stage. Boston, Mass: Harvard Business School Press.

37. Poljanec-Borić, S. (1994). Analiza španjolske, grčke i austrijske turističke kampanje. Turizam, 42 (7-8): 105-111.

38. Porter, M. E. (1998). The Competitive Advantage of Nations. New York: The Free Press.

39. Richter, K. L. (2007). Democracy and Tourism: Exploring the Nature of an Inconsistent Relationship, in: Burns, M. P. and Novelli, M. (Eds.). Tourism and Politics, Global Frameworks and Local Realities. Oxford, UK: Elsevier.

40. Riedel, H. (2013). Small States and International Security: Theoretical Consideration and Opportunities - The Case of Slovenia. Malta: University of Malta. (Accessed on May 10, 2015). Available at: (https://www.academia.edu/4460310/ Small_States_and_International_Security_Theoretical_Considerations_and_Opportunities. The Case of Slovenia).

41. Schimmelfenning, F. and Sedemeir, U. (2004). Governance by Conditionality: EU Rule Transfer to the Candidate Countries of Central and Eastern Europe. Journal of European Public Diplomacy, 11 (84): 661-679.

42. Slovenian Tourist Board /STB/ (2011). Od lipovega lista prek šopka rožic do I feel Slovenia. Accessed on May, 11, 2014. Available at: (http://www.slovenia. info/?zgodovina znamke $=0 \& \operatorname{lng}=1$ ).

43. Slovenian Tourist Board /STB/ (2012). Slovenski turizem v številkah. Accessed on May, 11, 2014. Available at: (http://www.slovenia.info/pictures/TB board/atachments 1/2013/tvs brosura 2012 slo web 16569.pdf).

44. Slovenian Alps (2014). Gorenjska katalog. Accessed on May 12, 2014. Available at: (http://www.slovenian-alps.com/en/files/default/programi/zgodbe/pdf/gorenjska katalog_ENG[1].pdf).

45. Szondi, G. (2007). The Role and Challenges of Country Branding in Transition Countries: The Central and Eastern European Experience. Place Branding and Public Diplomacy, 3: 8-20.

46. Szondi, G. (2008). Public Diplomacy and Nation Branding: Conceptual Similarities and Differences, Netherlands Institute of International Relations „Clingendall“. Accessed on November 11, 2015. Available at: (http://www.clingendael.nl/sites/ default/files/20081022 pap in dip nation branding.pdf).

47. Tulmets, E. (2014). East Central European Foreign Policy Identity in Perspective. [Online]. Accessed on November 20, 2015. Available at: (http://www.palgraveconnect.com/pc/doifinder/10.1057/9781137315762.0001.).

48. Van de Walle, S. (2010). Building Local Communities: Place-Shaping as NationBuilding. Lex Localis - Journal for Local Self Government, 8 (1): 23-33.

49. Vinšćak, T. (2002). Vjerovanja o drveću u Hrvata u kontekstu slavističkih istraživanja (Beliefs About Trees among Croatia in the Context of Slavic Studies). Jastrebarsko: Naklada Slap. 
Saša Poljanec-Borić

Institut društvenih znanosti Ivo Pilar, Zagreb, Hrvatska

e-mail:sasa.boric@pilar.hr

\section{Upravljanje brendom destinacije kao podrška stvaranju političkog identiteta: Slučaj Slovenije}

\section{Sažetak}

Članak se bavi analizom razvoja slovenskog konkurentskog identiteta u posljednjih dvadeset godina kroz marketinšku i političku perspektivu. Razmatraju se okolnosti nastanka prvog slovenskog destinacijskog brenda. Kako bi se pokazala međuovisnost između razvoja destinacijskog brenda i političkog marketinga, analizira se vremenska podudarnost između objavljivanja novih slovenskih turističkih brendova i političkih koraka koje je Slovenija poduzimala između 1990. i 2007. godine. Budući da je Slovenija počela razvijati novi turistički brend dok je još bila dio Socijalističke Federativne Republike Jugoslavije, ukazuje se na vezu između političkog procesa stjecanja nezavisnosti i destinacijskog brendiranja. Promjena identiteta brenda događala se svaki put kad je Slovenija poduzimala odlučne političke korake usmjerene na pristup Europskoj uniji. Stoga se tvrdi da je razvijanje slovenskog turističkog brenda bilo usklađeno s razvojem političkog procesa pristupanja Europskoj uniji. Pokazuje se da je Slovenija stabilizirala konkurentski identitet u vrijeme svoga pristupanja schengenskoj i eurozoni. Tvrdi se da je ta okolnost snažna potvrda da je u Sloveniji postojala duboka veza između turističkog i političkog marketinga u promatranom razdoblju. Na kraju se sugerira da je slovenski proces upravljanja brendom destinacije jedinstven u novoj Europi te da ga treba evaluirati u odnosu na druge relevantne prakse destinacijskog brendiranja u novoj Europi i u svijetu.

Ključne riječi: turizam, politika, marketing, brend, konkurentski identitet, Slovenija, Europska unija. 